\title{
Unconfined hypogene evaporite karst: West Texas and southeastern New Mexico, USA
}

\author{
Kevin W. Stafford*, Jon Ehrhart, Adam Majzoub, Jessica Shields, and Wesley Brown \\ Department of Geology, Stephen F. Austin State University, Nacogdoches, TX 75962, USA
}

\begin{abstract}
Diverse karst phenomena occur throughout the Gypsum Plain where the Castile Formation crops out over $\sim 1800 \mathrm{~km}^{2}$ in West Texas and southeastern New Mexico. Hypergene karst is extensive and widespread, while traditional hypogene karst manifestations (both caves and intrastratal dissolution) occur in high frequency in the western outcrop region where surface denudation has been the greatest so as to induce surficial breaching. Unconfined hypogene karst occurrences have been recently identified, including two general variations: 1) artesianlike discharge features; and 2) venting structures. Artesian-like discharge features arise at surficially-breached hypogene caves and through high permeability regions on the margins of breccia pipes; these occur when aquifer pressures within the underlying Bell Canyon siliciclastics are sufficiently elevated subsequent to anomalously high precipitation events. Venting structures associated with condensation corrosion-like processes coupled with ascending moisture-rich vapor occur as fracture vents and hydration buckles; fracture vents develop along near-vertical joint sets and hydration buckles form at intermittent zones of high permeability within the core regions of breccia pipes. All venting structures form highly porous, low density, secondary sulfate mineralization at the land surface, creating local topographic highs decimeters to a meter in scale that preclude interception of meteoric waters into these unconfined hypogene karst features. The Gypsum Plain hosts complex karst phenomena that present unique engineering challenges as variable geohazard occurrences ranging from shallow, hypergene caves to deep, complex, hypogene features both formed in semi-confined and unconfined speleogenetic conditions.
\end{abstract}

Keywords: $\quad$ karst, evaporite, hypogene, resistivity, Delaware Basin

Received 11 December 2017; Revised 11 June 2018; Accepted 20 June 2018

Citation: $\quad$ Stafford K.W., Ehrhart J., Majzoub A., Shields J. and Brown W., 2018. Unconfined hypogene evaporite karst: West Texas and southeastern New Mexico, USA. International Journal of Speleology, 47 (3), 293-305. Tampa, FL (USA) ISSN 0392-6672 https://doi.org/10.5038/1827-806X.47.3.2166

\section{INTRODUCTION}

Evaporite karst development is extensive and widespread throughout the greater Permian Basin of southeastern New Mexico and West Texas, including manifestations ranging from surficial karren and shallow hypergene karst features to complex and extensive hypogene karst systems. Over the past decade, the region has been studied more intensely with increased emphases on natural resource management because of extensive petroleum exploration and development throughout the Delaware Basin (Stafford \& Faulkner, 2016). Concerns of geohazards encountered during infrastructure development and drilling operations have prompted these recent interests in evaporite karst manifestations. Therefore, studies to delineate and characterize these geohazards have enabled researchers in the region to identify greater variability within hypogene karst processes affecting Permian evaporites, specifically within the Castile Formation, than previously recognized (Stafford et al., 2017a,b). These include traditionally-defined hypogene karst formed in semi-confined conditions as well as hypogene karst formed in unconfined conditions as reported in this manuscript.

The Castile Formation crops out over approximately $1800 \mathrm{~km}^{2}$ in southeastern New Mexico and West Texas in what is commonly referred to as the Gypsum Plain (Fig. 1). The Gypsum Plain extends from the Apache Mountains in the south to the Guadalupe Mountains in the north with strata dipping gently eastward throughout the region. The Gypsum Plain is bounded to the west by outcrops of the underlying Bell Canyon siliciclastics that are exposed in the Delaware Mountains and to the east by overlying residuum of the Salado and Rustler formations of the Rustler Hills. The region is located on the northern edge of the Chihuahua Desert with an average annual 


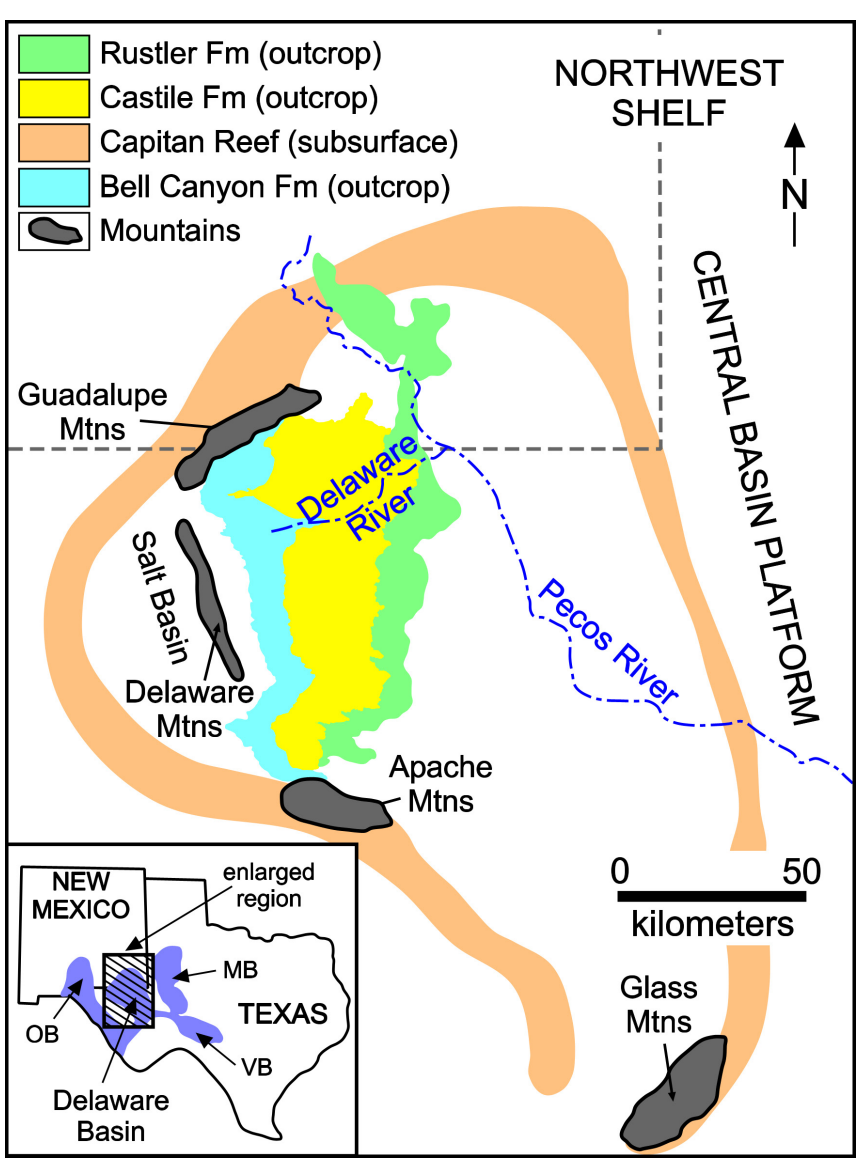

Fig. 1. Location map of the Delaware Basin and Gypsum Plain, including outcrops of relevant lithologic units and major geology and hydrologic structures (adapted from Stafford, 2017). Inset map shows relationship of study area to West Texas, New Mexico and the greater Permian Basin including the Delaware Basin, Orogrande Basin (OB), Midland Basin (MB) and Val Verde Basin (VB).

precipitation of $267 \mathrm{~mm}$ that primarily occurs as late summer monsoonal storm events (Sares, 1984); however, decadal-scale rain events can occur within the area contributing more than $100 \mathrm{~mm}$ of precipitation over broad areas within less than 48 hours (Stafford et al., 2017a). Average annual temperature is $17.3^{\circ} \mathrm{C}$, with an average annual low and high of $9.2^{\circ} \mathrm{C}$ and $25.2^{\circ} \mathrm{C}$, respectively (Sares, 1984).

Although the region is arid today, it was significantly wetter during the Pleistocene (Hill, 1996). Sinkholes, solution troughs and valleys often exhibit thick Quaternary alluvial deposits (Bachman, 1980) which are currently being heavily exploited as water resources for oilfield and ranching activities. Arroyos and ephemeral streams exhibit flash flooding during intense precipitation events; however, the Delaware River, a tributary of the Pecos River, is the only perennial stream that bisects the Gypsum Plain. Surface hydrology throughout the Cenozoic has been dominated by migration of the Pecos River across the Delaware Basin providing a persistent, eastwardmigrating potentiometric low for upward flow and hypogene processes (Thomas, 1972; Stafford et al., 2009).

\section{GEOLOGIC SETTING}

The Delaware Basin, and associated evaporite strata, resulted from the formation of Pangea during the late Permian. As North American and South American-
African plates began colliding in the Carboniferous, the ancestral Tobosa Basin of southeastern New Mexico and West Texas was divided into the Delaware Basin, Midland Basin and Val Verde Basin (see inset in Fig. 1) through block faulting and compression associated with the developing Marathon Fold and Thrust Belt (Horak, 1985; Ross, 1986). At this time, the Delaware Basin was located within $5-10^{\circ}$ of the equator on the western edge of Pangea where effects of the Ouachita orogenic zone would have created arid conditions (Lottes \& Rowley, 1990). The Central Basin Platform, which divides the Delaware and Midland basins, was uplifted, isolating the basins into inland seas with limited open marine circulation to the Panthalassic Ocean during the Permian. Most authors (e.g., King, 1942; Scholle et al., 2004; Kirkland \& Kirkland, 2018) suggest that during the Guadalupian, marine connectivity to the Delaware Basin was maintained through the Hovey Channel which enabled massive carbonate reefs to thrive around the periphery of the basin, forming the Capitan Reef system; however, Hill (1999) suggests that the Guadalupian marine inlet to the Delaware Basin may have actually been positioned near the Glass Mountains in what she described as the Diablo Channel. In both scenarios, contemporaneous with reef development, shallow water carbonates and evaporites of the Artesia Group (Fig. 2) were deposited across the Central Basin Platform and Northwestern Shelf (Scholle et al., 2004) (Fig. 1). At times of sealevel lows, shelf regions transitioned into sabkhalike depositional settings producing more extensive interbedded evaporites and siliciclastics proximal to the Capitan Reef. At maximum Guadalupian lowstands, eolian sands migrated across exposed shelfal regions to deposit siliciclastic-rich facies into the Delaware Basin interior which largely comprise the Cherry Canyon and Bell Canyon formations (Scholle et al., 2004) (Fig. 2).

At the end of the Guadalupian, loss of open marine connectivity by progradational reef growth and sealevel lowering transitioned the Delaware Basin into a restricted, inland sea with a shift from carbonatedominated deposition to evaporite-dominated deposition (Adams, 1972; Anderson et al., 1972). This marked the beginning of the Ochoan, a period of basin infilling and capping by evaporite strata throughout the greater Permian Basin, including the Delaware and Midland basins as well as surrounding shelfal regions. The Castile Formation represents the earliest phase of Ochoan evaporite infilling and is limited to the Delaware Basin where it occurs as laminated evaporite strata (Anderson \& Kirkland, 1966). Castile strata were deposited within a stratified, brine-filled basin bound by the Capitan reef and characterized as laminated to massive gypsum/anhydrite interbedded with halite, where laminated sulfates represent seasonal changes in basinal salinity (Anderson et al., 1972). Sulfate strata laminae consist of couplets of calcite and gypsum/anhydrite, where calcite laminae represent less saline or "wet" periods and gypsum/ anhydrite laminae represent more saline or "dry" periods (Anderson et al., 1972). The Castile reaches a maximum thickness of 480 meters in the subsurface 
SHELF

REEF

DELAWARE BASIN

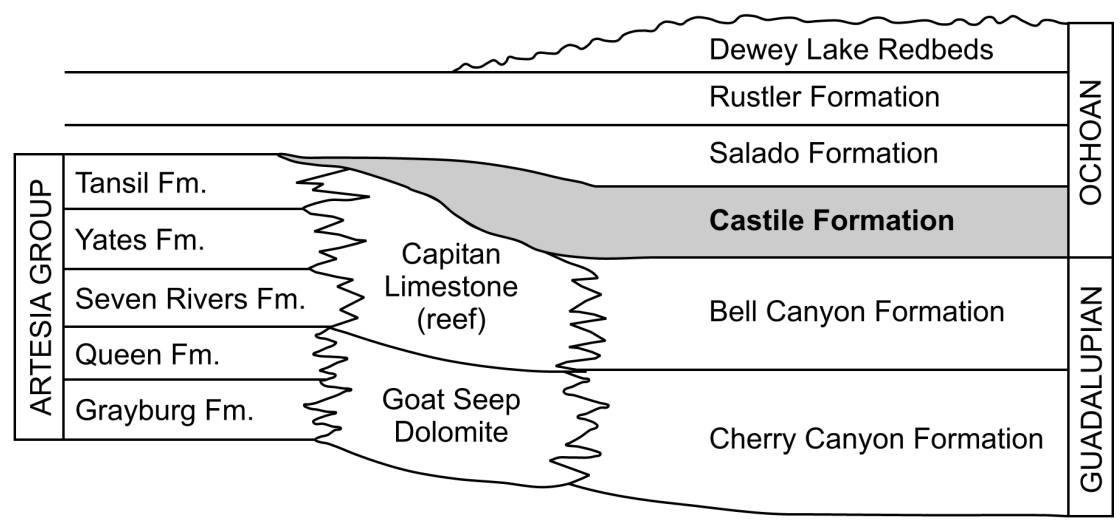

Fig. 2. Stratigraphic diagram of formations of the Delaware Basin region, including basin, reef and shelf facies with the Castile Formation highlighted in grey (adapted from Scholle et al., 2004).

in the eastern Delaware Basin but thins to a solutional margin in the west where it crops out (Kelley, 1971).

By mid-Ochoan, Castile strata filled the Delaware Basin and evaporite deposition extended onto surrounding shelves and across the Midland Basin. The Salado Formation caps the Castile and is subsequently capped by the Rustler Formation and Dewey Lake Redbeds (Hill, 1996). The Salado Formation is dominated by chloride minerals, primarily halite, that have been solutionally removed from outcrop and shallow subcrop regions throughout the greater basin, but reaches thicknesses of 600 meters in the subsurface (Kelley, 1971). The Rustler Formation was deposited as a series of five major sealevel advances/retreats and is characterized by cyclic deposits of carbonate and sulfate strata (Hill, 1996), marking the last major episode of evaporite deposition for the region. The Dewey Lake Redbeds cap Ochoan strata and consist of transitional, siliciclastic-rich facies representing the final regression of Permian seas and a shift into continental deposition for the region (Hill, 1996).

Throughout the Mesozoic and Cenozoic, the Permian Basin region has largely remained above sea-level and dominated by continental processes since Pangea rifting (Horak, 1985), excluding a brief period of marine transgression in the late Cretaceous. By the end of the Mesozoic, the region was uplifted significantly above sea level with stratal tilting of $3-5^{\circ}$ towards the east/northeast due to Laramide tectonism (Dickinson, 1981; Hentz \& Henry, 1989). The Laramide Orogeny had little additional effect on the region. Subsequent Basin and Range tectonism in the Neogene down-dropped the far western edge of the Delaware Basin, but exhibited only minor effect on the greater Permian Basin region. However, the extensional regime did induce conjugate jointing/ faulting throughout the Delaware Basin with general orientations of $\sim \mathrm{N} 75^{\circ} \mathrm{E}$ and $\sim \mathrm{N} 15^{\circ} \mathrm{W}$ (Nance, 1993). Igneous activity associated with late Basin and Range extension emplaced dike structures within the northern Delaware Basin in the Neogene and elevated the regional thermal gradients (Hentz \& Henry, 1989).

The modern geomorphic landscape of the Delaware Basin, and specifically that of the Gypsum Plain where the Castile Formation crops out, is the result of combined karst processes and climatic shifts from wetter, sub-humid conditions of the Pleistocene to arid conditions of the Holocene (Bachman, 1980; Hill, 1996). Shallow alluvial aquifers occur throughout the Gypsum Plain where Quaternary infilling of solution valleys and ephemeral streams provide storativity. While the Castile Formation itself does not host significant water resources, the underlying Bell Canyon siliciclastic aquifer system provides groundwater that is recharged in outcrop to the west of the Gypsum Plain that migrates beneath the Castile and provides aggressive fluids for hypogene speleogenesis (e.g., Stafford, 2017a). Lee and Williams (2000) have modeled the paleo and current hydrogeology of the Delaware Basin, which indicates that much of the diagenesis of the Permian evaporites is associated with ascension of waters from the Bell Canyon and Cherry Canyon aquifers; these aquifers are mixing with more deeply-derived ascending fluids, including hydrocarbons from basinal units.

\section{TRADITIONAL CASTILE KARST}

Karst research throughout Delaware Basin evaporites and specifically the Castile Formation have identified widespread hypergene and hypogene speleogenetic processes. Hypergene karst occurrences are dominated by surficial geomorphic expression of heavy karren development on exposed gypsum surfaces as well as extensive solutional sinkhole development (Fig. 3A) often associated with welldeveloped, dendritic arroyo drainage networks. While solutional sinkholes usually encompass multihectare watersheds, associated caves are generally laterally-limited with solutional conduit aperture size decreasing rapidly away from insurgences. Hypergene caves are dominantly fracture controlled with smallscale scallops on wall surfaces (Fig. 3B) attesting to rapid groundwater recharge along brittle deformation zones during intense rain events when overland flow and arroyo interception is high. Most hypergene caves are limited to a few tens of meters in lateral length as humanly passable structures and often exhibit abrupt passage direction changes associated with interception of fluid flow along conjugate joint sets generally oriented at $\sim \mathrm{N} 45^{\circ} \mathrm{E}$ and $\sim \mathrm{N} 40^{\circ} \mathrm{W}$ (Stafford et al., 2008a).

Hypogene karst has been well-documented throughout the Castile Formation with manifestations ranging from simple, largely isolated chambers (e.g., China Mine), to complex, multi-story and laterallyextensive cave systems developed within heavily folded and fractured bedrock (e.g., Dead Bunny Hole), to vertically-extensive, single riser-tube features (e.g., Crystal Cave) to intrastratal brecciation (Stafford et al., 2008a). These manifestations occur in greatest abundance on the western edge of the Castile outcrop area where evaporite stratal thickness is heavily reduced by surface denudation. These hypogene 
karst manifestations developed at the boundary with the underlying Bell Canyon aquifer which is locally near the land surface (i.e., less than 200 meters) (Stafford et al., 2008b). Hypogene manifestations generally exhibit little correlation with local variations in gypsum texture and commonly cut across laminated, nodular, massive and selenitic fabrics. Stafford (2017) identified four major variations on traditional hypogene karst within Delaware Basin evaporites based on the dominance of speleogenetic drivers, including: 1) fluvial-induced hypogene karst; 2) pressure gradient-dominated hypogene karst; 3) density convection-dominated hypogene karst; and 4) hydrocarbon-enhanced hypogene karst. While all of these hypogenic variations show evidence of coupled forced and free convection flow in semiconfinement during formation, each type exhibits distinct dominance of a major driving component in the resulting hypogene manifestation.

Fluvial-induced hypogene karst has been documented throughout the greater Delaware Basin region primarily in association with the eastward migration of the Pecos River throughout the Cenozoic (Anderson \& Kirkland, 1980; Stafford et al., 2009). Large-scale manifestations include major subsidence features throughout the central portion of the Delaware Basin as well as along the eastern edge of the Delaware Basin where evaporite strata overlie the buried Capitan Reef. Throughout the Castile outcrop area, direct evidence of fluvial-induced hypogene karst is less distinct, but smaller-scale, subsidence troughs and deeply-entrenched, fluvial valleys are common and appear to be the primary result of upward migration of fluids towards a major potentiometric low in the past, but have been significantly overprinted by Neogene to recent surficial processes.

Pressure gradient-dominated hypogene karst is most heavily developed along the western edge of the Castile outcrop area. Here, high hydrostatic pressures within the underlying Bell Canyon aquifer system has produced complex, multi-storey caves (Fig. 3C), single riser-tube caves, and isolated "vug" caves, depending on the extent of fracturing locally within the host rock. It is probable that significant pressure gradient-dominated hypogene karst exists throughout the Castile proximal to the underlying siliciclastic aquifer contact and that a sampling bias exists in the western outcrop region as a result of greater surface denudation (Stafford et al., 2008b). Many of these surficially-breached caves exhibit
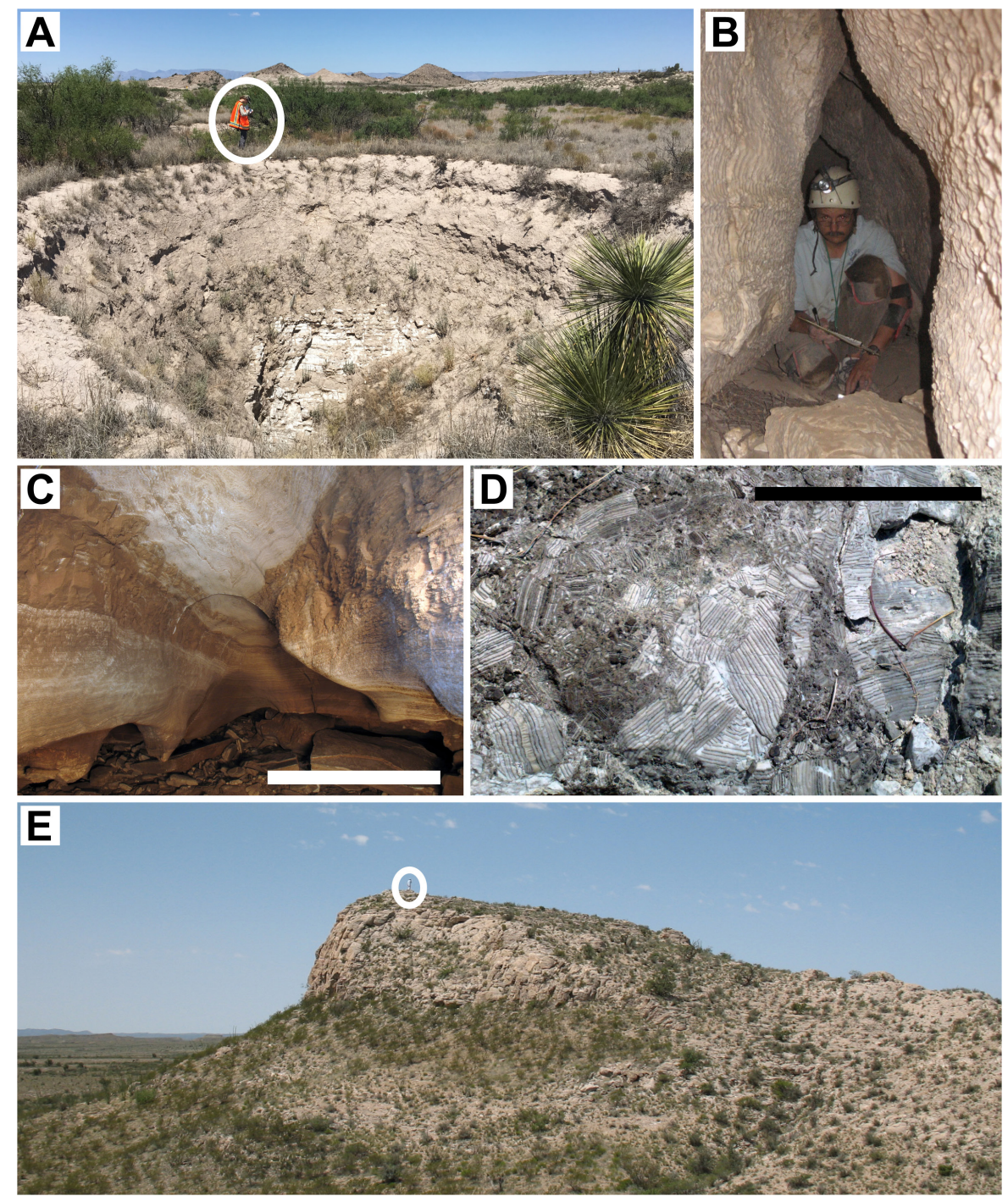

Fig. 3. Traditional karst manifestations within the Gypsum Plain, including: A) sinkholes; B) hypergene caves; C) hypogene caves; D) intrastratal brecciation; E) calcitized evaporites forming "castile buttes." People circled for scale (A, E); white scale is approximately $100 \mathrm{~cm}(C)$; black scale bar is approximately $20 \mathrm{~cm}(\mathrm{D})$. 
artesian-like discharge following multiple intense rain events when groundwater recharge into Bell Canyon siliciclastics to the west creates high enough pressures to significantly raise the local potentiometric surface (Fig. 4).

Density convection-dominated hypogene karst occurs primarily as intrastratal brecciation (Fig. 3D) both as vertically-extensive breccia pipes and laterally-extensive blanket breccias (Anderson et al., 1978; Stafford et al., 2008c). Intrastratal brecciation results from solutionally-aggressive fluids delivered either vertically or laterally into preferentially soluble zones such that the resulting void structure can no longer support overlying strata. In breccia pipes within the Castile Formation, ascending fluids create soluble zones initially as pressure gradient-dominated karst at the underlying contact with the Bell Canyon Formation. As void size increases, collapse and upward stoping occurs, such that density convection flow within the collapse structure continuously delivers solutionally aggressive fluids upwards through the stoping structure thus enabling collapse
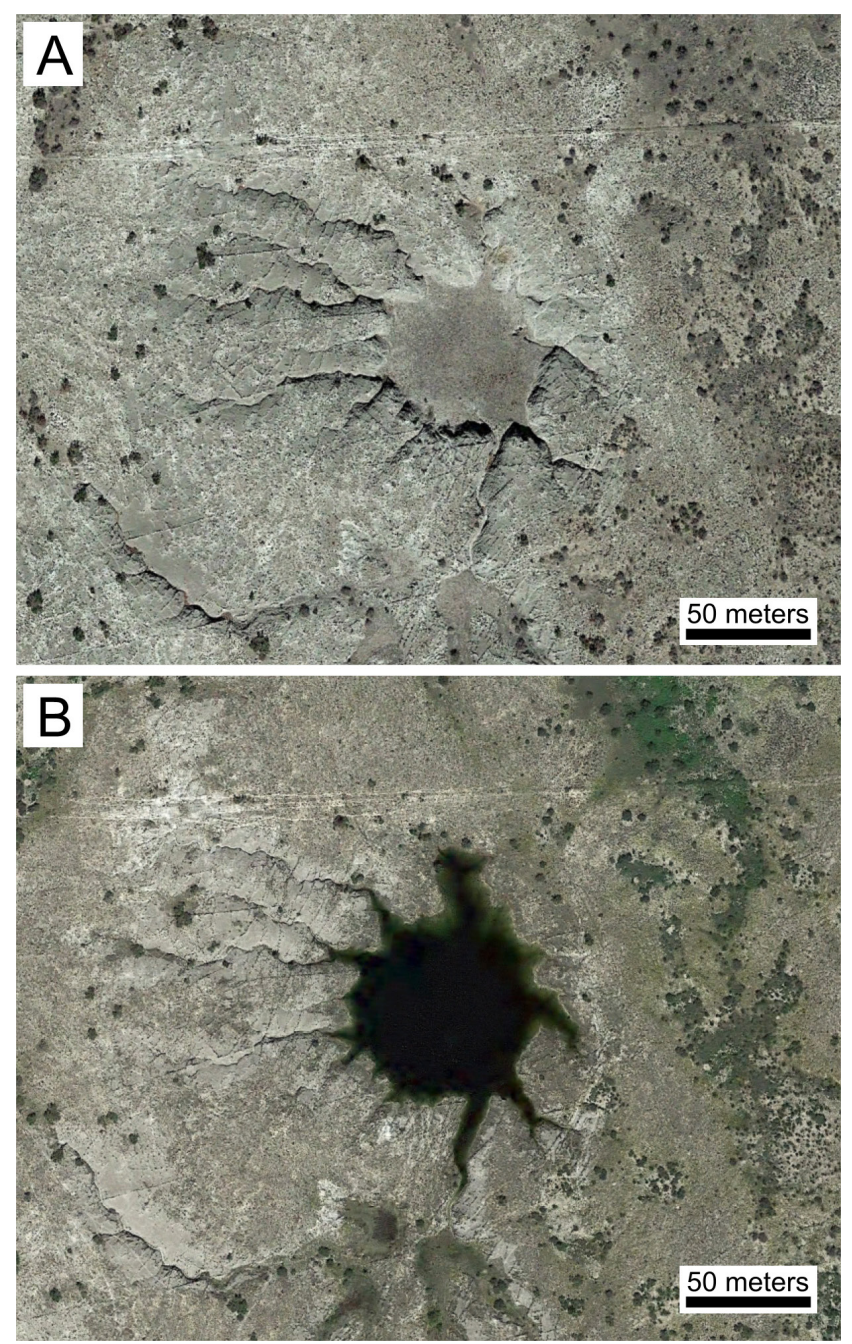

Fig. 4. Satellite imagery of a large sinkhole associated with a known hypogene cave in the Castile Formation as it appeared on January 22, 2013 (A) and on October 1, 2014 (B) (images from Google Earth, 2017). Local ranchers report that the sinkhole was filled by ascending waters following intense rain events in September, 2014, and that the sinkhole remained filled with water for more than a year. This region is known to host numerous hypogene caves that have stoped to the surface creating collapse sinkholes that discharge artesian water when hydrostatic pressure in the underlying Bell Canyon aquifer increases following intense or prolonged precipitation events. structures up to several hundred meters in diameter to propagate vertically through the entire thickness of the evaporite strata. Similarly, blanket breccias form through updip, lateral migration of ascending fluids, but are generally associated with dissolution of halite interbeds within Castile strata such that widespread collapse occurs along solutionally removed halite horizons. In contrast to breccia pipes, blanket breccias are generally only a few decimeters thick but may extend laterally over several square kilometers.

Hydrocarbon-enhanced hypogene karst broadly overprints all other hypogene karst manifestations but includes extensive diagenetic alteration of sulfates within the Castile Formation. Evaporite calcitization is common throughout the Gypsum Plain where light hydrocarbons have migrated updip through the Bell Canyon and Castile formations, fueling sulfate reduction (Kirkland \& Evans, 1976). Although it is inconclusive at this point as to whether calcitization was dominantly produced through bacterial sulfate reduction or thermochemical sulfate reduction (Stafford et al., 2008c), the resulting manifestations include calcitized masses, often referred to as "castile buttes and masses" (Fig. 3E), as well as extensive native sulfur deposits that were economically mined throughout the twentieth century (Lee \& Williams, 2000). Hill (1996) and Stafford et al. (2008c) have documented active degassing still occurring at several "castile buttes" within the Gypsum Plain, indicating that these processes are still active in the region. Evaporite calcitization occurs commonly near the contact between the Bell Canyon and Castile formations, but is most often observed and associated with intrastratal brecciation (Wallace \& Crawford, 1992) where these high permeability structures provided preferential flow paths for upward migration of light hydrocarbons. In many instances, calcitized masses that have been exposed at the land surface through surface denudation continue to expel hydrocarbon-rich gases, based on discernable odor and the presence of powdery, secondary gypsum deposits at degassing locations (Stafford et al., 2008c).

\section{NON-CONFINED CASTILE HYPOGENE KARST}

Although classically-defined hypogene karst forms in confined to semi-confined hydrogeologic systems, karst manifestations within the Castile outcrop of the Gypsum Plain indicate that hypogene karst can form, or continues to develop, in unconfined conditions. The examples provided above of classical hypogene manifestations indicate that numerous karst features exist within the study area that were formed in semiconfined conditions that have been subsequently breached by surface denudation and overprinted by hypergene processes. Artesian discharge through breached hypogene caves has been documented within the Gypsum Plain as well as unconfined hypogene manifestation associated with solutionally-widened fractures, heavily leached bedrock within subsidence valleys, and brecciated zones. These unconfined hypogene phenomena can be largely classified into two groups: 1) Artesian Discharge; and 2) Venting Structures. 


\section{Artesian Discharge}

Many traditionally-defined hypogene features intermittently exhibit artesian-like discharge that commonly induces ponding at the land surface following intense precipitation events across the region. These intense rain events produce significant recharge into the Bell Canyon aquifer system and substantially raise the potentiometric surface across the Gypsum Plain (Stafford \& Faulkner, 2016). Such an event occurred in late September 2014 and is attributed to anomalously high precipitation in September 2013 and September 2014, when 250-400 $\mathrm{mm}$ of precipitation occurred within in 48 hours during each of these late monsoonal season events. Because the region is sparsely populated and land is largely privately owned, monitoring wells do not exist within the area to accurately document this occurrence. However, Google Earth imagery captured on October 1, 2014 does document widespread ponding of waters within known hypogene karst features that have been breached by surface denudation (Fig. 4). While imagery alone does not prove that ponding was induced by upward migration of fluids, reports by employees of the Texas Department of Transportation (TxDOT) in the area confirm that following the September 2014 large precipitation event water was observed at many locations discharging from the ground with great enough force to form minor "artesian springs" with pressure heads greater than five centimeters above the land surface (Stafford et al., 2017b). This "artesian discharge" behavior was reported as occurring at both known hypogene caves that have been breached and within broad subsidence valleys where bedrock is highly fractured. Based on limited evidence available, it appears that the intense September 2013 precipitation event significantly recharged the Bell Canyon aquifer system and elevated potentiometric pressures within it, likely increasing formation of pressure gradient-dominated hypogene dissolution at the Bell Canyon/Castile contact. The following year, September 2014 event, repeated the same general precipitation pattern and thus induced greater recharge into the Bell Canyon aquifer system such that the already elevated potentiometric pressures were increased and exceeded the land surface. Similar to reports from TxDOT employees, local ranchers in the region confirm these observations and indicate that this type of "artesian discharge" phenomenon occurs every 30-40 years.

Field observations of hypogene caves that have experienced "artesian discharge" do not provide conclusive evidence of ascension of fluids subsequent to initial porosity formation prior to breaching because most "artesian" ponding within these features subsequently drains back through the same flow paths as potentiometric pressures lower, creating additional apparent hypergene overprinting. However, geologic evidence of this groundwater ascension has been documented in association with brecciated zones and subsidence valleys where "artesian discharge" was reported by TxDOT employees. Where road infrastructure passes through these broad subsidence valleys in which "artesian discharge" has been reported, extensive road failure has occurred over the past few years primarily in the form of general road sagging and minor collapse. Excavations conducted at these sites identified that the underlying bedrock is highly-fractured and leached, such that significant portions (up to $30 \%$ ) of gypsum laminae have been solutionally removed (Fig. 5A). Based on reports of hydrogeologic conditions in September 2014 and field observations, shallow intrastratal dissolution occurs in these regions when potentiometric pressures are high enough in the Bell Canyon aquifer to propagate fluids upwards through evaporite strata. Currently, road failures associated with this intrastratal dissolution of evaporite laminae are the result of reequilibration within the system as bedrock that was dissolved and buoyantly supported during shortterm "artesian discharge" conditions compacts and stabilizes within the "normal" hydrogeologic regime of the area. Effectively, brief episodes of high potentiometric pressures induce localized intrastratal dissolution within shallow bedrock where soluble fractions are quickly removed from the system through "artesian discharge" and subsequent overland flow to ephemeral streams.

At the periphery of breccia pipes, "artesian discharge" was also documented following anomalously high precipitation events. Bedrock exposures of breccia pipes consistently display well-cemented internal structures (Fig. 5B) that often develop into topographic highs as a product of surface denudation; breccia pipes generally contain abundant calcite secondary cement or are near-completely calcitized (Kirkland \& Evans, 1976). However, at the periphery of breccia pipes, high permeability zones are common (Fig. 5C) which is expected based on general conceptual models of breccia pipe development. In order to further asses the permeability structure associated with breccia pipe margins where "artesian discharge" has been documented, a combination of electrical resistivity analyses and field excavations were conducted. Direct Current (DC) resistivity analyses were conducted with an AGI (Advanced Geoscience Inc.) SuperSting R8/ IP multi-electrode resistivity meter with 56 electrodes spaced at four meter intervals in a dipole-dipole array. DC resistivity data was reduced with AGI's EarthImager 2D software with smoothed model inversion and elevation correction from LiDAR (Light Detection and Ranging) data with a horizontal and vertical accuracy of $50 \mathrm{~cm}$ and $10 \mathrm{~cm}$, respectively (Ehrhart, 2016; Majzoub, 2017). Excavations were conducted at DC resistivity sites through standard backhoe trenching.

DC resistivity data from the transitional zone of the core of a large, 500-meter-diameter, breccia pipe illustrate well the high permeability outer boundary as well as minor regions of increased permeability within the central portion of the structure (Fig. 6). DC resistivity imaging confirms the presence of preferential flow paths at the transitional zone between brecciated cores and largely unaltered host rock within the Castile Formation. Because these transitions generally occur on relatively steep slopes bounding the margins of topographic highs created by 

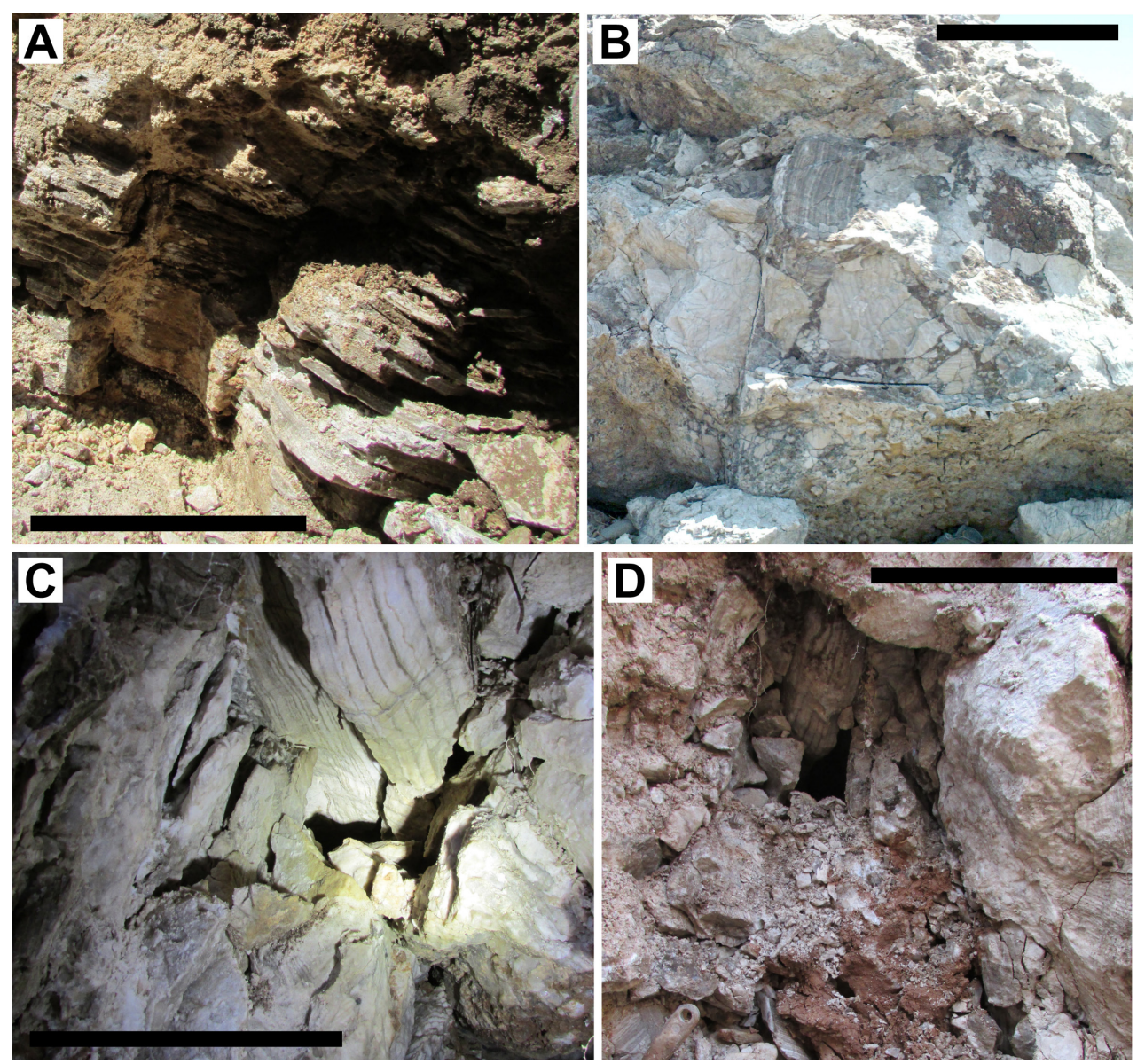

Fig. 5. Unconfined karst features associated with artesian discharge: A) intrastratal dissolution and leaching of gypsum laminae in highly fractured rock within a solution subsidence valley that exhibited artesian discharge in the September 2014 precipitation event; B-D) breccia pipe permeability variability including well-cemented breccia near the breccia pipe core $(B)$ and poorly-cemented and permeable breccia at margins of breccia pipe (C-D). Note extensive insoluble residue in near-surface breccia as indicated by red clay (D). Scale bars are approximately $25 \mathrm{~cm}$.

differential surface denudation, they do not appear to intercept significant overland flow and thus are not being heavily influenced by meteoric processes, but instead appear to be zones that are only hydrologically active when potentiometric pressures in the Bell Canyon aquifer are sufficient to induce artesian-like conditions. Excavations within these breccia pipes provide evidence to support DC resistivity analyses; towards the center of breccia cores, brecciation is well cemented (Fig. 5B). Excavations at the margin of breccia pipes identified heavily fractured rock with solutional widening that appears to have resulted from sluggish flow regimes (Fig. 5C) including minor nearsurface clay accumulations that appear to be largely insoluble residues (Fig. 5D) and not typical alluvial soils found in outcrop throughout the Gypsum Plain.

In addition to artesian-like discharge associated with anomalously high aquifer pressures within the Gypsum Plain, sparsely-distributed, lowflow, persistent artesian springs do occur at a few locations. These springs generally exhibit a strong "rotten eggs" odor suggestive of a significant hydrogen sulfide component (Stafford et al. 2008c). Many of these springs contain abundant colonies of white, filamentous bacteria proximal to the spring orifices and actively discharge gas bubbles, likely as a result of decreasing fluid pressure proximal to the land surface (Nance \& Stafford, 2009). They appear to retain relatively consistent flow and do not show significant variation in discharge between extended periods of drought or periods of intense monsoonal activity. These features remain effectively unstudied, but likely represent mixed fluid sources including hydrocarbon-rich fluids, likely derived from basinal waters, and fluids ascending from the underlying Bell Canyon aquifer. More study is needed on these features to define the fluid sources and unravel the complexities of these isolated, persistent springs.

\section{Venting Structures}

Venting structures include features associated with both fracture networks and breccia pipes within the Gypsum Plain and are characterized as minor topographic highs that often exhibit expulsion of air with high moisture content. Features are commonly recognized as topographic ridges within relatively flat landscapes when associated with fracture networks or as clusters of domal structures when associated with breccia pipes. All venting structures are characterized by heavily recrystallized, highly porous and friable secondary gypsum at the land surface which largely comprises and often replaces original gypsum fabrics.

Fracture vents (i.e., venting structures developed along fractures) generally occur in highly fractured bedrock with closely-spaced fracture sets. Associated topographic ridges range from 40 to $150 \mathrm{~cm}$ in height with comparable widths (Fig. 7A, B, E) and exhibit interfracture regions that form low depressions, often 

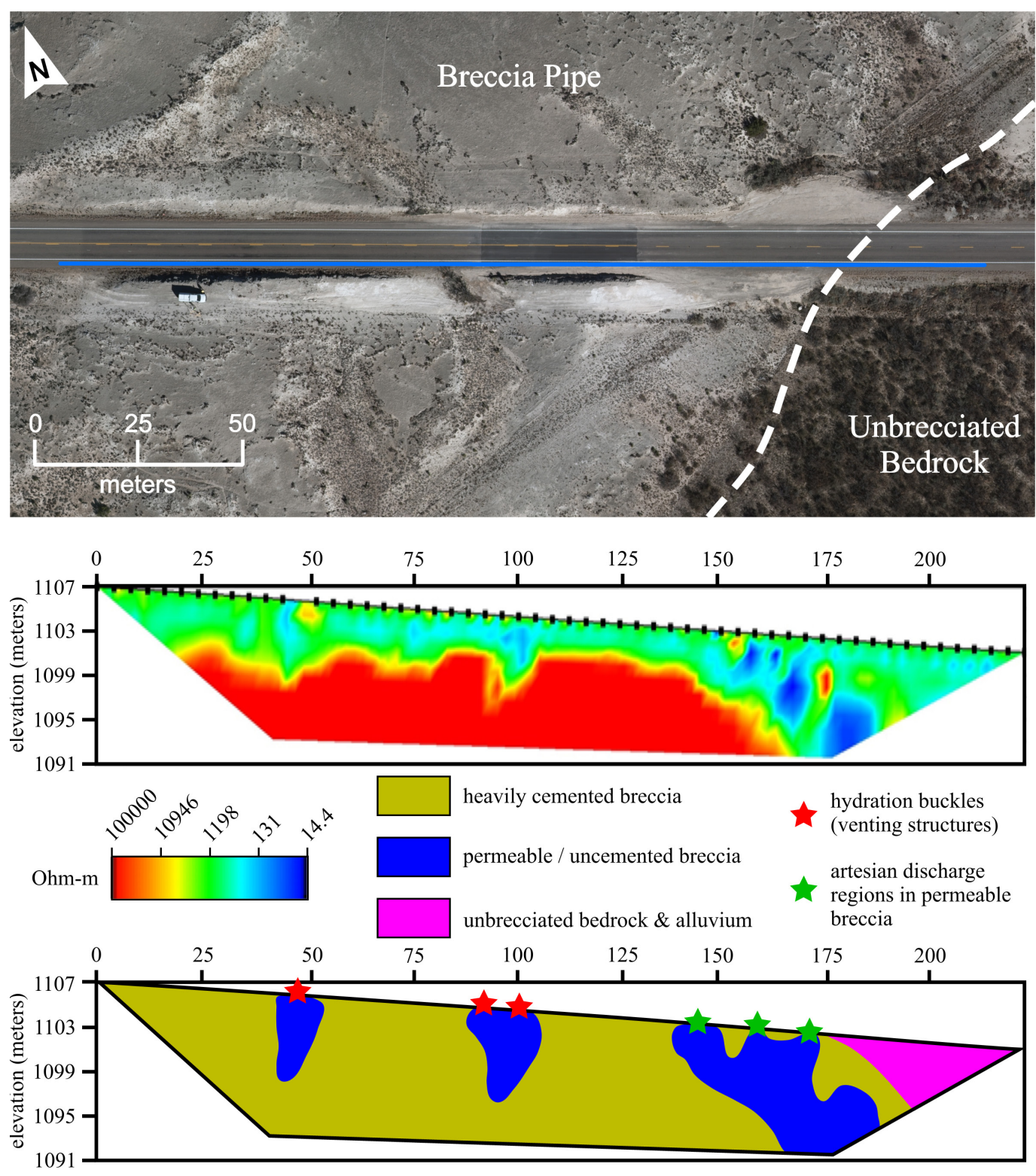

Fig. 6. DC resistivity analyses associated with breccia pipe development. Upper image depicts relationship orthoimagery to a 224-m-long survey (blue line) conducted parallel to a road in Culberson County, Texas (note that the dashed white line in the orthoimagery marks the approximate transition from the brecciated to the unbrecciated regions in outcrop). Lower images include DC resistivity profile (RMS 14.2\%) and interpretation. Note that the core of the breccia pipe is highly cemented (Fig. 5B) with high resistivity values, while porous and permeable zones within and on the margin of the breccia pipe are delineated in dark blue in the interpretation. Hydration buckles associated with unconfined hypogene karst development were documented towards the center of the survey region (red stars), while artesian discharge regions were documented at the margins (green stars) and confirmed in field excavations (see Fig. 5C-D).

floored with cryptogamic soils (Fig. 7E). Superficially, fracture vents mimic pressure ridges, but true pressure ridges in the area rarely exceed $10 \mathrm{~cm}$ in height and $30 \mathrm{~cm}$ in width, but may laterally extend for tens of meters forming polygonal networks within gypsic crusts. Most ridges associated with fracture vents do not exhibit any surficial connectivity or breach points, but at intermittent intervals small collapse structures occur through the central crest of the fracture ridge (Fig. 7D). These breach points intercept verticallywidened fracture planes that appear to extend for at least tens of meters deep with widths of centimeters to decimeters based on field borescope observations; however, most are too narrow for human exploration or when large enough for human entry only extend for a few meters before becoming impassable (Fig. 7D). All observed fracture vents that had been breached exhibit solutional widening with smooth cuspate morphologies and significant accumulations of vapor moisture on rock surfaces (Fig. 7C). In regions where fracture vents with breached crests have been documented, the underlying Bell Canyon aquifer is generally within $100 \mathrm{~m}$ depth. It is probable that these fractures propagate downward through the Castile Formation to the Bell Canyon contact providing direct connectivity to the underlying aquifer system.

While fracture vents were not documented in regions of known or even suspected "artesian discharge" in the September 2014 precipitation event, it is likely that the potentiometric surface at that time was significantly elevated within these fractures. DC resistivity studies with 56 electrodes were conducted at locations where fracture vents were documented; however, instead of acquiring DC resistivity data in a single acquisition phase, a roll-along survey was conducted with one 

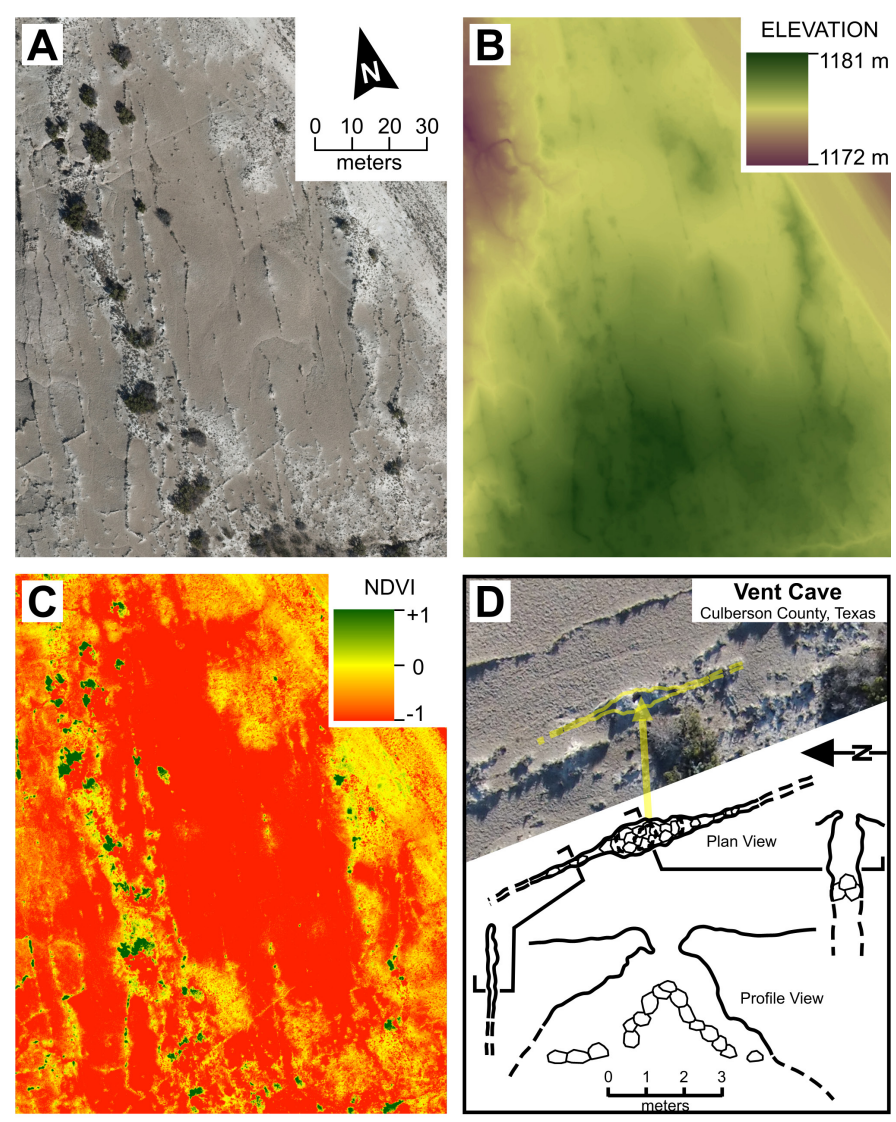

E

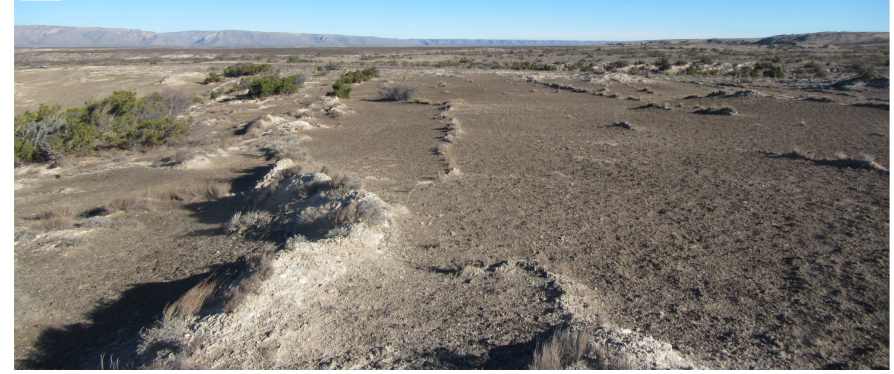

Fig. 7. Fracture vent occurrences of unconfined hypogene karst. Orthophoto $(A)$ and drone imagery $(E)$ coupled with digital elevation model $(B)$ show elevated ridges and interfracture lows with cryptogamic soils that are associated with fracture vents. Normalized Density Vegetation Index (C) shows higher moisture flux (green) associated with many of the fracture vents. Vent Cave (D) illustrates the typical solutional-widening observed when fracture vents are breached at the land surface.

meter spacing, instead of four meter spacing used for breccia pipes, in order to better resolve small fracture widths (Fig. 8). Data from these sites indicate high permeability, near-vertical fractures that correlate well with surficial expressions of venting fractures based on aerial imagery and in-field investigations. This confirms that unbreached fracture vents retain the same general morphology and porosity structure of the intermittently breached features and do extend to depths of greater than ten meters.

In association with breccia pipes, hydration buckles (i.e., venting structures developed in association with collapse breccia) occur in clusters of elliptical, dome-like structures (Fig. 9A-C) that superficially appear similar to tumuli (Fig. 9D) but lack open cavity structures generally found within centimeters beneath the surface of tumuli. Hydration buckles are generally composed of highly porous and friable clasts of breccia that retain semblances of original gypsum fabric and are coupled within decimeters to one meter of the land surface to highly permeable breccia zones. However, these occurrences generally form near the crest of topographic highs created by differential erosion of the breccia pipes in contrast to the "artesian discharge" features documented at the margins of the breccia structures. Shallow excavation into these structures consistently encountered elevated vapor moisture and at times secondary gypsum recrystallization along breccia clast boundaries (Fig. 9C). While not specifically investigated through DC resistivity analyses, data collected at breccia-pipe boundaries to document permeable "artesian discharge" zones was collected that included minor hydration buckle phenomena (Fig. 6). As with fracture vents, hydration buckles generally occur at topographic highs coupled with localized doming that precludes any significant interception of meteoric waters to these features. Therefore, like fracture vents, hydration buckles appear to be largely associated with moisture-rich vapor ascension through permeable zones that are coupled with deeper water sources.
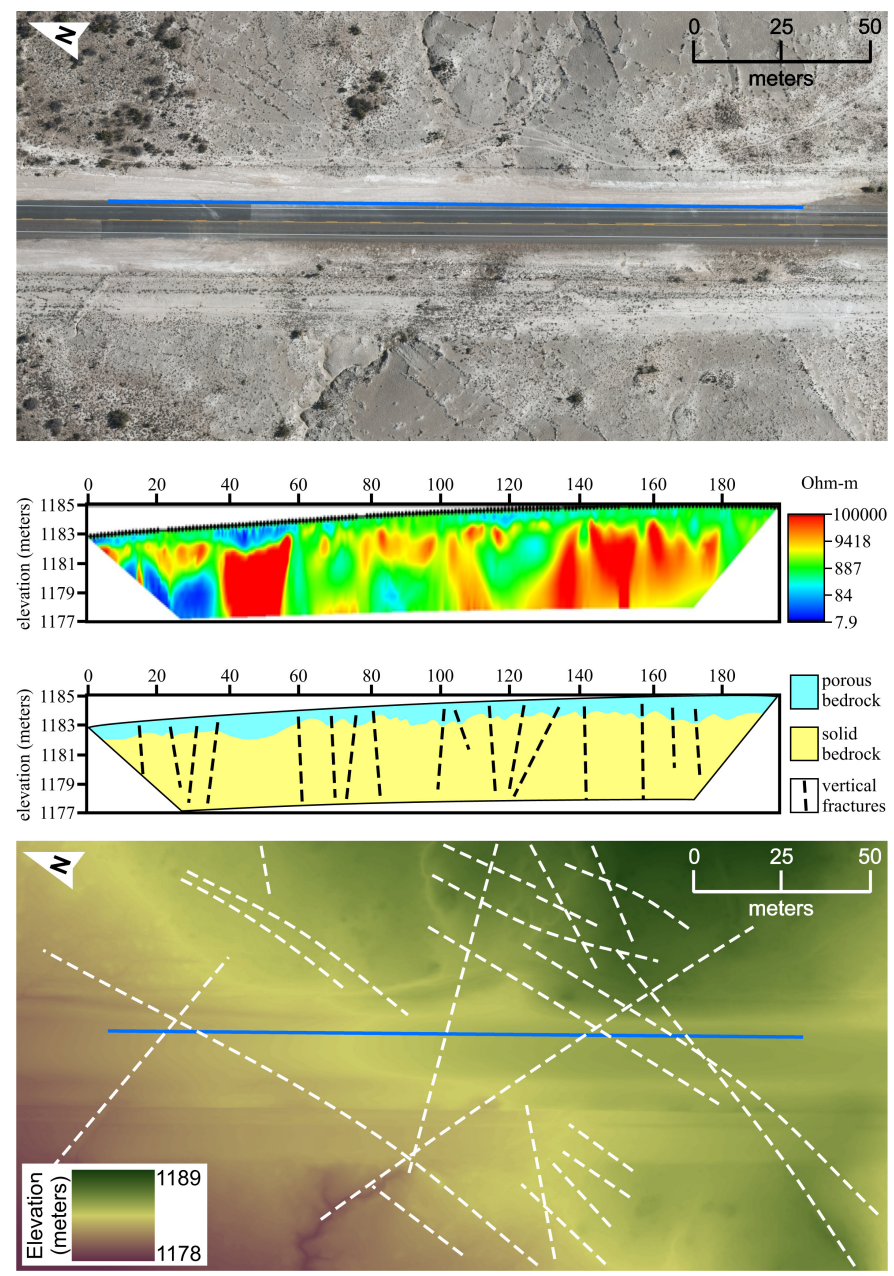

Fig. 8. DC resistivity analyses associated with unbreached fracture vents. Upper image depicts relationship of orthoimagery to a 196-m-long survey (blue line) conducted parallel to a road in Culberson County, Texas (note the well-defined lineaments in imagery data that are fracture vent ridges). Lower image shows same spatial area as upper image, but as a digital elevation model with major lineaments (i.e., fracture vents) marked with dashed white lines. Middle images include DC resistivity profile (RMS $9.5 \%$ ) and interpretation. The low resistivity region proximal to the land surface is interpreted as porous bedrock with mixed indurated gypsic alluvium, while black dashed lines indicate probable zone of near-vertical fractures that are associated with unconfined hypogene karst forming fracture vents. 

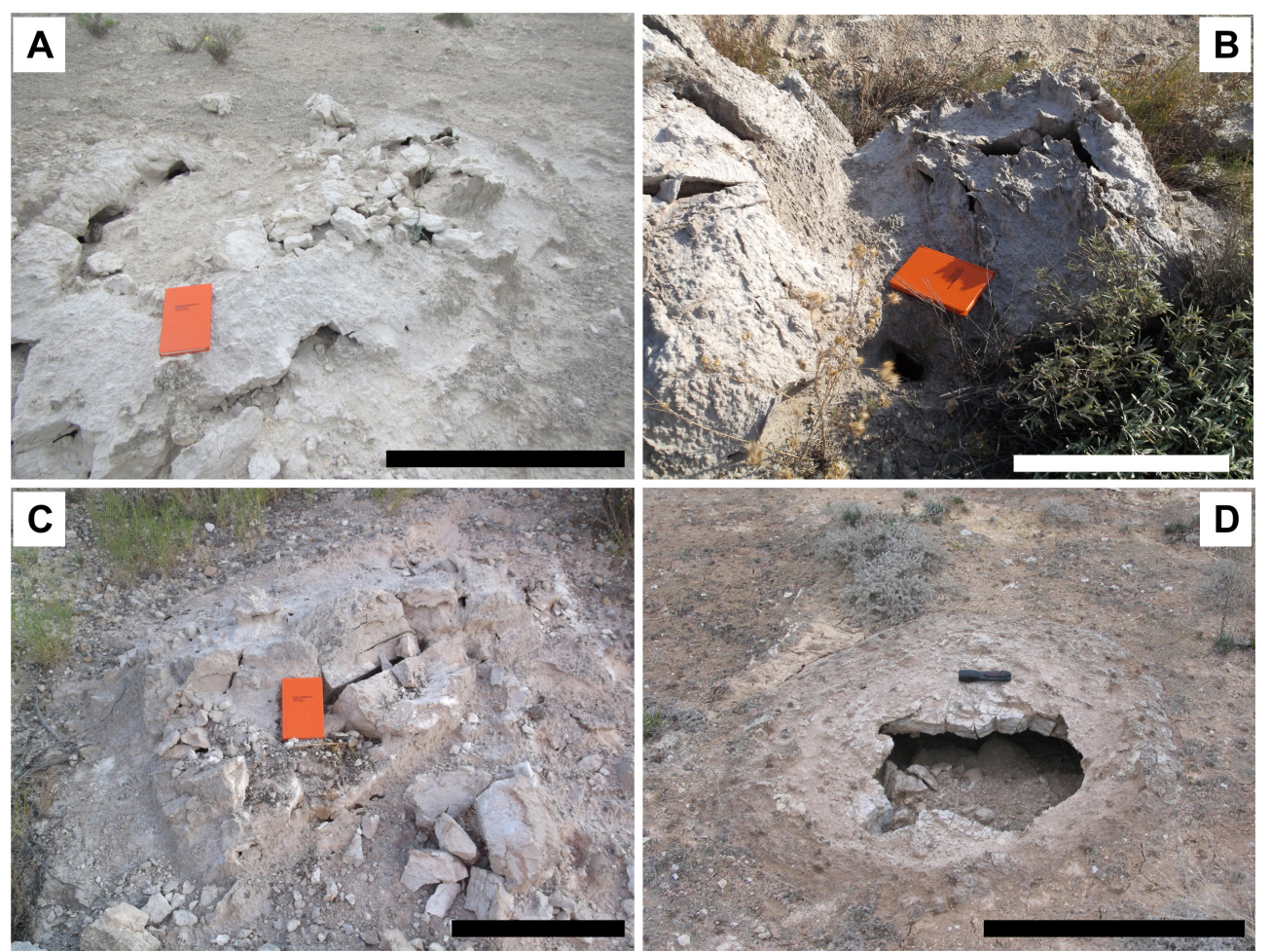

Fig. 9. Domal surface structures within the Gypsum Plain include both hydration buckles (A-C) formed as non-confined hypogene karst and classic gypsum tumuli (D) formed as weathering crusts. Note smooth domal structure of gypsum tumuli (D) versus more irregular surfaces of hydration buckles (A$B$ ) and the distinct difference in internal structures, where tumuli form hollow voids (D) and hydration buckles are composed of porous, altered gypsum breccia (C). Scale bars are approximately $50 \mathrm{~cm}$.

Venting structures, both fracture vents and hydration buckles, within the Castile outcrop area exhibit distinct similarities although they occur as different geomorphic expressions. These features consistently exhibit high moisture vapors within near surface pore space and have extensively recrystallized sulfate mineralization at the land surface extending up to a meter into the subsurface. These features appear to be the result of upward convection of solutionallyaggressive water vapor derived from volatilization of water from the underlying Bell Canyon aquifer which condenses on fracture/breccia clasts, dissolving rock surfaces and increasing porosity similar to that described for condensation corrosion in other karst settings (Ford \& Williams, 2007). Saturated waters then likely descend through the pore structure and are returned to the underlying Bell Canyon aquifer system. However, water vapor that approaches the land surface and dissolves near-surface sulfate rocks quickly evaporates in the arid conditions of the Gypsum Plain, thus promoting re-precipitation of highly porous material that is low density with increased volume and creating buckling associated with the crests which form fracture ridges and hydration buckles. Effectively, the near-surface recrystallization of sulfate rocks subsequently precludes the interception of surficial water from recharging into these features thus effectively isolating these unconfined hypogene features from meteoric processes.

\section{DISCUSSION}

Many studies over the past decade have focused on hypogene speleogenesis ranging from morphological variability to geological and geochemical environments associated with formation. In general, discussions on hypogene karst over the past decade have largely followed the definition of Ford (2006), where he defined hypogene speleogenesis as: “. . . the formation of caves by water that recharges the soluble formation from underlying strata, driven by hydrostatic pressure or other sources of energy, independent of recharge from the overlying or immediately adjacent surface." Klimchouk (2007) noted that "Hypogene development may continue in unconfined setttings, but confined conditions are the most essential element of hypogenic speleogenesis." Because confinement is often considered essential for hypogene processes, often semi-confined to confined conditions are implied to be requisites for hypogene karst to develop as noted by Mylroie and Mylroie (2009) where they describe hypogene karst as ". . . dissolution of carbonates and evaporites in confined or semi-confined settings." However, numerous examples of unconfined hypogene speleogenesis have been documented over the past decade. The massive cenote-like structures at Sistema Zacatón reported by Gary and Sharp (2009) as volcanogenic karstification have been associated with hypogene speleogenesis where volcanic gases provide additional solutional aggressivity of ascending fluids through thick carbonate strata. Land (2009) documented ascension of waters from the San Andres artesian aquifer upwards through interbedded evaporites of the Artesia Group towards the Pecos River in eastern New Mexico as a mechanism for the formation of cenote-like structures of Bottomless Lakes State Park. Schindel et al. (2008) introduced the concept of hypogene processes associated with the Edwards aquifer in central Texas in order to characterize the artesian flow regimes within this 
complex aquifer system that is directly coupled with hypergene karst porosity in near adjacent regions. While these only represent a small fraction of the diversity of hypogene karst manifestations that exist in unconfined settings, they all include components of upward migration of fluids through soluble zones that are at least locally decoupled from immediate influences of meteoric processes.

Clearly, unconfined karst features associated with artesian-like discharge within the Castile Formation of the Gypsum Plain fall within the scheme of hypogene karst as defined by Ford (2006) and in many instances represent a continuum of hypogene karst that originally formed in semi-confined conditions that continue to be intermittently and hydrologically active as hypogene caves in unconfined conditions. Venting structures, both fracture vents and hydration buckles, similarly exhibit characteristics of unconfined speleogenesis that are potentially linked to earlier phases of semi-confined hypogene development but are currently being modified by condensation-corrosion processes. While fracture vents and hydration buckles superficially fit into the general classification of pressure ridges and tumuli as examples of weathering crusts described by Macaluso and Sauro (1996), these features are not limited to surficial exposures. Instead, these features are coupled to deeper flow networks that descend well into the subsurface beyond the range of surficial crust development and commonly exhibit upward fluid (moisture-laden air) migration exiting from them, thus classifying them as unconfined hypogene karst.

Hypogene karst within the Castile Formation of the Gypsum Plain exhibits complex variability in manifestations rangingfromkarst porositydevelopment that formed in complete confinement to features that are associated with unconfined conditions. In many instances, original hypogene structures are heavily overprinted by hypergene processes when surface denudation breaches these features, although some of these continue to exhibit episodic hypogene activity associated with intermittent artesian-like discharge conditions. However, unconfined hypogene venting structures discussed within this manuscript effectively remain hydrologically isolated from surficial meteoric processes although they are coupled with the land surface. Local topographic highs created by ridge structures developed along fracture vents and domal structures created by hydration buckles prevent interception of any significant overland flow into these features even during intense rain events. While hydration buckles are related to permeable zones in breccia pipes created by an earlier phase of hypogene karst development, fracture vents do not definitively exhibit patterns of overprinting an earlier phase of confined to semi-confined hypogene origins. However, it is probable that these fracture vents are similar to the transverse flow model of Klimchouk (2009) for the Piedmont Range of the Crimean Mountains but continue to exhibit hypogene speleogenesis in the unconfined settings created by surface denudation because of the arid conditions of the southwestern United States.

\section{CONCLUSIONS}

Karst development within the Gypsum Plain is complex and represents multiple episodes of hypogene karst development, semi-confined and unconfined, as well as hypergene manifestations. Variable overprinting by hypergene processes complicates interpretations of karst phenomena, while the remote nature of the area with limited land access to researchers restricts regional comparison of karst manifestations across the entirety of the Gypsum Plain and other evaporite lithologies throughout the greater Permian Basin region. The unpredictable nature of weather patterns with anomalously high precipitation events occurring at decadal scales further hinders direct correlation of the modern hydrogeologic system to active karst development.

As research continues within the evaporites of the Castile Formation, the speleogenetic history and diversity of karst manifestations continues to expand in complexity. The unconfined hypogene karst manifestations reported in this manuscript add another level of speleogenesis to karst regions where arid conditions coupled with local geomorphic highs preclude significant influences of meteoric processes on surficially-connected hypogene karst features. As seen in other regions around the world, unique hypogene phenomena manifest in unconfined settings as long as these features remain largely decoupled from overland flow and direct influences of meteoric processes.

\section{ACKNOWLEDGEMENTS}

The authors thank the Texas Department of Transportation (TxDOT) and Stephen F. Austin State University for partial funding of this research. Aaron Eaves, Jonah Morris, Lillian O'Shay, and Jonathan Woodard provided generous field support throughout various stages of this project. The comments of reviewers are greatly appreciated in the improvement of this manuscript during the revision process.

\section{REFERENCES}

Adams J.E., 1972 - Semi-cyclicity in the Castile anhydrite. In: Elam J.G. \& Chuber S. (Eds.), Cyclic sedimentation in the Permian Basin. West Texas Geological Society, Midland, p. 196-202.

Anderson R.Y., Dean W.E., Kirkland D.W. \& Snider H.I., 1972 - Permian Castile varved evaporite sequence, West Texas and New Mexico. Geological Society of America Bulletin, 83: 59-85.

https://doi.org/10.1130/0016-7606(1972)83 [59:PCVESW]2.0.CO;2

Anderson R.Y., Kietzk K.K. \& Rhodes D.J., 1978 Development of dissolution breccias, northern Delaware Basin and adjacent areas. New Mexico Bureau of Mines and Mineral Resources, Circular 159, p. 47-52.

Anderson R.Y. \& Kirkland D.W., 1966 - Intrabasin varve correlation. Geological Society of America Bulletin, 77: 241-256.

https://doi.org/10.1130/0016-7606(1966)77 [241:IVC]2.0.CO;2 
Anderson R.Y. \& Kirkland D.W., 1980 - Dissolution of salt deposits by brine density flow. Geology, 8: 66-69. https://doi.org/10.1130/0091-7613(1980)8\%3C66: DOSDBB\%3E2.0.CO;2

Bachman G.O., 1980 - Regional geology and Cenozoic history of the Pecos Region, southeastern New Mexico. U.S. Geological Survey Open File Report 80-1099.

Dickenson W.R., 1981 - Plate tectonic evolution of the southern Cordillera. Arizona Geological Society Digest, 14: 113-135.

Ehrhart J., 2016 - Speleogenesis and delineation of megaporosity and karst geohazards through geologic cave mapping and LiDAR analyses associated with infrastructure in Culberson County, Texas. Unpublished MS Thesis, Stephen F. Austin State University, Nacogdoches, $159 \mathrm{p}$.

Ford D.C., 2006 - Karst geomorphology, caves and cave deposits: a review of North American contributions during the past half century. In: Harmon R.S. \& Wicks C.M. (Eds.), Perspectives on karst geomorphology, hydrology, and geochemistry - a tribute to Derek C. Ford and William B. White. Geological Society of America Special Paper 404, p. 1-14.

https://doi.org/10.1130/2006.2404(01)

Ford D. \& Williams P., 2007 - Karst hydrogeology and geomorphology. John Wiley \& Sons, Ltd, Chichester, 562 p. https://doi.org/10.1002/9781118684986

Gary M.O. \& SharpJ.M, 2009-Volcanogenickarstification: implications of this hypogene process. In: Stafford K.W., Land L. \& Veni G. (Eds.), NCKRI Symposium 1: Advances in hypogene karst studies. National Cave and Karst Research Institute, Carlsbad, p. 27-39.

Google Earth, 2017 - V7.1.2.20141. Digital image of Culberson County, Texas, Eye alt $1.8 \mathrm{~km}$. http:// ww.earth.google.com [Accessed on 20 November 2017].

Hentz T.F. \& Henry C.D., 1989 - Evaporite-hosted native sulfur in Trans-Pecos Texas: relation to late phase Basin and Range deformation. Geology, 17: 400-403. https://doi.org/10.1130/0091-7613(1989)017\%3C04 00:EHNSIT\%3E2.3.CO;2

Hill C.A., 1996 - Geology of the Delaware Basin, Guadalupe, Apache and Glass Mountains: New Mexico and west Texas. Permian Basin Section of the SEPM, Midland, $480 \mathrm{p}$.

Hill C.A., 1999 - Reevaluation of the Hovey Channel in the Delaware Basin, West Texas. AAPG Bulletin, 83 (2): 277-294. http://archives.datapages.com/data/bulletns/ 1999/02feb/0277/0277.htm

Horak R.L., 1985 - Trans-Pecos tectonism and its effects on the Permian Basin. In: Dickerson W.R. \& Muelberger W.M. (Eds.), Structure and tectonics of Trans-Pecos Texas. West Texas Geological Society, Midland, p. 81-87.

Kelly V.C., 1971 - Geology of the Pecos Country, southeastern New Mexico. New Mexico Bureau of Mines and Mineral Resources, Socorro, $72 \mathrm{p}$.

King P.B., 1942 - Permian of west Texas and southeastern New Mexico. AAPG Bulletin, 26 (4): 535-649.

https://doi.org/10.1306\%2F3D933466-16B1-11D7$8645000102 \mathrm{C} 1865 \mathrm{D}$

Kirkland D.W. \& Evans R., 1976 - Origin of limestone buttes, Gypsum Plain, Culberson County, Texas. AAPG Bulletin, 60: 2005-2018.

https://doi.org/10.1306\%2FC1EA3A1E-16C9-11D7$8645000102 \mathrm{C} 1865 \mathrm{D}$

Kirkland D.W. \& Kirkland B.L., 2018 - Postulated origin of Carlsbad Cavern, Lechuguilla Cave, and other hypogene caves, Guadalupe Mountains, West Texas and southeastern New Mexico. In: Stafford K.W. \& Veni G. (Eds.), Hypogene karst of Texas. Texas Speleological Survey, Austin, p. 16-35.
Klimchouk A., 2007 - Hypogene speleogenesis: hydrogeological and morphometric perspective. National Cave and Karst Research Institute, Carlsbad, 106 p.

Klimchouk A., 2009 - Principal features of hypogene speleogenesis. In: Klimchouk A. \& Ford D.C. (Eds.), Hypogene speleogenesis and karst hydrogeology of artesian basins. Ukrainian Institute of Speleology and Karstology, Simperfol, p. 7-16.

Land L., 2009 - The impact of hypogenic processes on water resources in the arid southwest: examples from the lower Pecos region of New Mexico, USA. In: Stafford K.W., Land L. \& Veni G. (Eds.), NCKRI Symposium 1: Advances in hypogene karst studies. National Cave and Karst Research Institute, Carlsbad, p. 149-156.

Lee M.K. \& Williams D.D., 2000 - Paleohydrology of the Delaware Basin, western Texas: overpressure development, hydrocarbon migration, and ore genesis. Bulletin of the American Association of Petroleum Geologists, 84 (7): 961-974.

https://doi.org/10.1306/A9673B80-1738-11D78645000102C1865D

Lottes A.L. \& Rowley D.B., 1990 - Reconstruction of the Laurasian and Gondwanan segments of Permian Pangea. In: McKerrow W.S. \& Scotese C.R. (Eds.), Paleozoic paleogeography and biogeography. Memoirs of the Geological Society of London, 12: 383-395. https://doi.org/10.1144/GSL.MEM.1990.012.01.36

Macaluso T. \& Sauro U., 1996. Weathering crust and karren on exposed gypsum surfaces. International Journal of Speleology 25 (3-4): 115-126. https://doi.org/10.5038/1827-806X.25.3.9

Majzoub A., 2017 - Characterization and delineation of karst geohazards along RM652 using electrical resistivity tomography, Culberson County, Texas. Unpublished MS Thesis, Stephen F. Austin State University, Nacogdoches, 106 p.

Mylroie J.E. \& Mylroie J.R., 2009 - Diagnostic features of hypogenic karst: is confined flow Necessary? In: Stafford K.W., Land L. \& Veni G. (Eds.), NCKRI Symposium 1: Advances in hypogene karst studies. National Cave and Karst Research Institute, Carlsbad, p. 12-26.

Nance R., 1993 - Application of the standard tablet method to a study of denudation in gypsum karst, Chosa Draw, southeastern New Mexico. Unpublished MS Thesis, University of Northern Colorado, Greely, $82 \mathrm{p}$.

Nance R. \& Stafford K.W., 2009 - The role of hypogene processes in sulfate reduction in the Castile Formation: Eddy County, New Mexico and Culberson County, Texas. In: Stafford K.W., Land L. \& Veni G. (Eds.), NCKRI Symposium 1: Advances in hypogene karst studies. National Cave and Karst Research Institute, Carlsbad, p. 71-84.

Ross C.A., 1986 - Paleozoic evolution of southern margin of Permian Basin. Bulletin of the Geological Society of America, 97: 536-554. https://doi.org/10.1130/0016-7606(1986)97\%3C536: PEOSMO\%3E2.0.CO;2

Schindel G.M., Johnson S.B. \& Alexander E.C., 2008 Hypogene processes in the Balcones fault zone Edwards aquifer in south-central Texas, a new conceptual model to explain dynamics. Geological Society of America Abstracts with Programs, 40 (6): 344.

Sares S.W., 1984 - Hydrologic and geomorphic development of a low relief evaporite karst drainage basin, southeastern New Mexico. Unpublished MS Thesis, University of New Mexico, Albuquerque, $123 \mathrm{p}$. Scholle P.A., Goldstein R.H. \& Ulmer-Scholle D.S., 2004 - Classic upper Paleozoic reefs and bioherms of west Texas and New Mexico. New Mexico Institute of Mining and Technology, Socorro, $166 \mathrm{p}$. 
Stafford K.W., 2017 - Hypogene evaporite karst of the greater Delaware Basin. In: Klimchouk A., Palmer A.N., De Waele, J., Auler A.S. \& Audra P. (Eds.), Hypogene karst regions and caves of the world. Springer International Publishing, Cham, p. 531-542. https://doi.org/10.1007/978-3-319-53348-3_32

Stafford K.W., Brown W., Ehrhart J.T., Majzoub A.F. \& Woodard J.W., 2017a - Evaporite karst geohazards in the Delaware Basin, Texas: review of traditional karst studies coupled with geophysical and remote sensing characterization. International Journal of Speleology, 46 (2): 169-180.

https://doi.org/10.5038/1827-806X.46.2.2089

Stafford K.W., Brown W., Morris J., O-Shay L. \& Shields J., 2017b - Karst geohazard characterization of RM 652: phase three of karst development and geohazards associated with RM 652 in Culberson County, Texas. Texas Department of Transportation, El Paso District, $56 \mathrm{p}$.

Stafford K.W. \& Faulkner M.S., 2016 - Engineering geohazards in hypogene evaporite karst, Castile Formation, west Texas. In: Chaves T. \& Reeling P. (Eds.), NCKRI Symposium 6: Proceedings of DeepKarst 2016, origins, resources, and management of hypogene karst. National Cave and Karst Research Institute, Carlsbad, p. 131-132.

Stafford K.W., Land L., Klimchouk A. \& Gary M., 2009 - The Pecos River hypogene speleogenetic province: a basin-scale karst paradigm for eastern New Mexico and west Texas. In: Stafford K.W., Land L. \& Veni G. (Eds.),
NCKRI Symposium 1: Advances in hypogene karst studies. National Cave and Karst Research Institute, Carlsbad, p. 121-135.

Stafford K.W., Nance R., Rosales-Lagarde L. \& Boston P.J., 2008a - Epigene and hypogene gypsum karst manifestations of the Castile Formation: Eddy County, New Mexico and Culberson County, Texas, USA. International Journal of Speleology, 37 (2): 83-98. https://doi.org/10.5038/1827-806X.37.2.1

Stafford K.W., Rosales-Lagarde L., \& Boston P.J., 2008b - Castile evaporite karst potential map of the Gypsum Plain, Eddy County, New Mexico and Culberson County, Texas: a GIS methodological comparison. Journal Cave and Karst Studies, 70 (1): 35-46.

http://ww.caves.org/pub/journal/PDF/v70/cave-7001-35.pdf

Stafford K.W., Ulmer-Scholle D. \& Rosales-Lagarde L., 2008c - Hypogene calcitization: evaporite diagenesis in the western Delaware Basin. Carbonates and Evaporites, 23 (2): 89-103.

https://doi.org/10.1007/BF03176155

Thomas R.G., 1972 - The geomorphic evolution of the Pecos River system. Baylor Geological Studies, Bulletin 22, 40 p.

Wallace C.S.A. \& Crawford J.E., 1992 - Geology of the Culberson ore body. In: Wessel G.R. \& Wimberly B.H. (Eds.), Native sulfur: developments in geology and Exploration. Society of Mining, Metallurgy, Exploration, Inc., Littleton, p. 91-105. 